\title{
The Phlebotominae Sand Fly (Diptera: Psychodidae) Fauna of Two Atlantic Rain Forest Reserves in the State of Rio de Janeiro, Brazil
}

\author{
Nataly A Souza ${ }^{+}$, Claudia A Andrade-Coêlho, Maurício L Vilela, \\ Elizabeth F Rangel
}

\author{
Departamento de Entomologia, Instituto Oswaldo Cruz-Fiocruz, Av. Brasil 4365, 21045-900 \\ Rio de Janeiro, RJ, Brasil
}

\begin{abstract}
During two consecutive years, studies on the sand fly fauna in Poço das Antas and Fazenda Bom Retiro, two Atlantic Rain Forest Reserves from the State of Rio de Janeiro, were performed using Shannon traps, CDC light traps and human bait collections. Eleven species were identified; Lutzomyia longipalpis, L. migonei, L. edwardsi, L. intermedia, L. whitmani, L. fischeri, L. shannoni, L. ayrozai, L. hirsuta, L. monticola and L. misionensis (first occurrence in the State of Rio de Janeiro). L. intermedia and L. whitmani were the predominant anthropophilic species around houses, while L. hirsuta predominated in the forest.
\end{abstract}

Key words: Phlebotominae - ecology - Atlantic Rain Forest - preserved areas - Rio de Janeiro - Brazil

The Atlantic Forest of Brazil presents considerable biodiversity and is important in the epidemiology of American cutaneous leishmaniasis (ACL). Although Atlantic Forest once covered $12 \%$ of Brazilian territory, only about $7 \%$ of its original area remains. Human activities have almost completely destroyed this habitat and are now affecting large areas of the Amazon and Cerrado (http://www.wwf.org.br). Although mainly associated with primary forest in the past, ACL now occurs in areas affected by human colonization, agriculture, land development and mining. It is possible that some sand fly species are modifying their biting behaviour, affecting their role in Leishmania transmission. In recent years, several studies of ACL epidemiology have been made in the State of Rio de Janeiro, Brazil, where most of the endemic area is periurban or rural.

The aim of this study was to increase knowledge of the sand fly fauna in two municipalities of the State of Rio de Janeiro (where remnants of

Supported by Fiocruz and CNPq/Brazil.

The authors dedicate this paper in honour of the Oswaldo Cruz Institute, on the occasion of the centenary of its foundation on May 25th 1900.

${ }^{+}$Corresponding author. Fax: +55-21-290.9339

E-mail: souzana@gene.dbbm.fiocruz.br

Received 12 April 2000

Accepted 14 November 2000
Atlantic Forest occur, i.e., Silva Jardim and Casimiro de Abreu, located 110 and $140 \mathrm{~km}$ respectively from the city of Rio de Janeiro (Fig. 1). In the past this region was entirely covered by the Atlantic Forest, and presented a humid climate throughout the year with two somewhat drier months in certain years, when humidity was kept concentrated in the mountains. The Atlantic Forest biome occupies an area that lies principally between the states of Rio Grande do Norte and Espírito Santo, with a branch extending further south to the Osório Mountains in Rio Grande do Sul. It is characterized by trees of the genera Cariniana, Arauracaria, Cedrela, Ficus, Tabebuia, Melanoxylin and Cesalpinia (http://www.wwf. org.br). Following the construction of the BR101 highway the vegetation cover has been significantly changed by human activities and only two preserved areas remain: the Poço das Antas Biological Reserve and the Reserva Particular de Patrimônio Natural on the Fazenda Bom Retiro. Both reserves have been mapped for the reintroduction, management and monitoring of the golden lion tamarin (Leontopithecus rosalia L.).

Sand fly collections were carried out on four consecutive days each month from July 1996 to June 1998 at the following sites: Area I - "Rodolfo Norte" and "Rodolfo Sul", two stations with the same kind of vegetation cover located in mature secondary forest on the Poço das Antas Reserve. The São João river is the main watercourse in this 

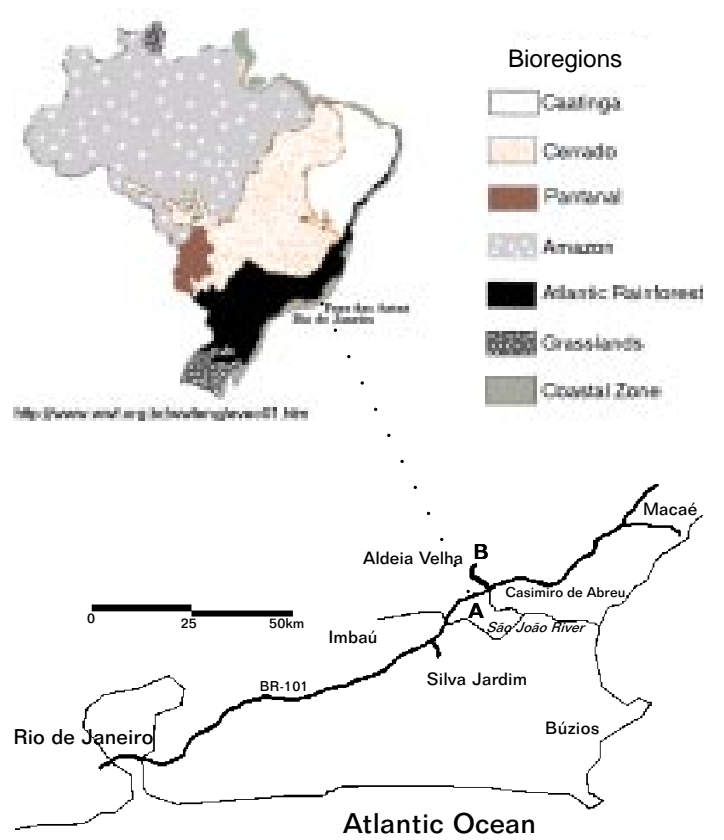

Fig.1: study areas. A: "Poço das Antas" Biological Reserve; B: Fazenda Bom Retiro (Natural Heritage Reserve)

reserve and inundates certain areas, causing the growth of characteristic species such as "pau de tamanco" (Tabebuia cassinoides), Callophyllum brasiliense and "guanandi" (Symphonia globulifera) (http://www.jbrj.gov.br); Area II - station located in secondary forest on the Bom Retiro Reserve. The vegetation consists of large trees (25$30 \mathrm{~m}$ high), bushes, woody climbing plants, palms and epiphytes. It has been relatively little disturbed by human action but banana trees have been planted in the forest; Area III - station located in and around houses on the Bom Retiro Reserve. This area has been largely deforested and is now occupied by human dwellings, animal shelters and plantations of manioc, palm heart, coconut, mango, papaya and other fruit trees. Illuminated Shannon trap (Alexander 2000) and human bait collections were used in peridomestic and forested sites while CDC light traps (Sudia \& Chamberlain 1962) were used in domestic animal shelters and close to the burrows of wild animals. Area I was $22 \mathrm{~km}$ distant from Areas II and III, which were $483 \mathrm{~m}$ apart.

A total of 12 CDC light traps were distributed in the three study areas and remained at the collection stations for four consecutive days, being switched on from 6 p.m. to 6 a.m. every night. The traps were distributed as follows: Area I - two each at the Rodolfo Norte and Rodolfo Sul stations. CDC traps were placed close $(\sim 1 \mathrm{~m})$ to the burrows of wild animals, as well as $1 \mathrm{~m}$ above the buttress roots of large trees; Area II - two each next to rock crevices on a mountainside and in a banana plantation; Area III - one trap placed in a manioc plantation, one in a chicken house and two in a stable containing horses and cattle.

Shannon traps manned by two human volunteers were used each night in different parts of Areas I and II. In Area III sand flies were collected simultaneously off human bait and the walls of houses. All these collections were made between 6 and 10 p.m.

During the two years of sampling daily temperature varied from $10-26^{\circ} \mathrm{C}$ during the period from June-August to $30-34^{\circ} \mathrm{C}$ in January-March. Relative humidity was $80-90 \%$ and annual rainfall approximately $2,400 \mathrm{~mm}$.

An overall total of 24,234 sand flies were collected in 2,688 $\mathrm{h}$ of sampling. The total number of sand flies collected from Areas I, II and III and identified to species according to Young and Duncan (1994) are shown in Tables I, II and III, respectively. Seasonal changes in the number of sand flies collected are presented for the most common species in Fig. 2.

TABLE I

Sand fly fauna of Poço das Antas Biological Reserve (mature secondary forest), Silva Jardim, RJ, Brazil; July 1996 - June 1998

\begin{tabular}{|c|c|c|c|c|c|c|c|}
\hline \multirow[t]{2}{*}{ Sand fly species } & \multicolumn{2}{|c|}{ CDC light trap } & \multicolumn{2}{|c|}{ Shannon trap } & \multirow{2}{*}{$\frac{\text { Human bait }}{\mathrm{F}}$} & \multirow[t]{2}{*}{ Total } & \multirow[t]{2}{*}{$\%$} \\
\hline & $\mathrm{F}$ & M & $\mathrm{F}$ & $\mathrm{M}$ & & & \\
\hline Lutzomyia edwardsi (Mangabeira, 1941) & 22 & 16 & 12 & 8 & 0 & 58 & 1,1 \\
\hline L. shannoni (Dyar, 1929) & 15 & 23 & 14 & 17 & 1 & 70 & 1,3 \\
\hline L. barrettoi(Mangabeira, 1942) & 16 & 9 & 9 & 28 & 0 & 62 & 1,2 \\
\hline L. intermedia (Lutz \& Neiva, 1912) & 32 & 19 & 28 & 23 & 2 & 104 & 1,9 \\
\hline L. whitmani (Antunes \& Coutinho, 1939) & 76 & 47 & 38 & 32 & 7 & 200 & 3,7 \\
\hline L. ayrozai (Barreto \& Coutinho, 1940) & 985 & 579 & 386 & 180 & 26 & 2,156 & 40,1 \\
\hline L. hirsuta (Mangabeira, 1942) & 863 & 663 & 406 & 339 & 347 & 2,618 & 48,7 \\
\hline L. monticola (Costa Lima, 1932) & 24 & 30 & 22 & 24 & 8 & 108 & 2,0 \\
\hline Total & \multicolumn{2}{|c|}{3,419} & \multicolumn{2}{|c|}{1,566} & 391 & 5,376 & 100 \\
\hline
\end{tabular}


The predominant species in Area I (mature secondary forest) were Lutzomyia ayrozai (Barretto \& Coutinho) and L. hirsuta (Mangabeira), which accounted for $89 \%$ of all sand flies collected. The former was more abundant in the months with high temperature and humidity while the latter predominated during the cooler, drier months (Fig. 2). This species showed diurnal activity on cloudy days, although only small numbers of flies were collected during daylight hours (three females in August 1997, eight females in November 1997 and two females and six males in March 1998). Daytime activity of these species was previously observed by Aguiar and Soucasaux (1984) and Aguiar et al. (1985) in the Serra dos Órgãos National Park, in the State of Rio de Janeiro. They made up $92 \%$ of all sand flies collected in the park and L. hirsuta was particularly anthropophilic in wooded areas, as observed during the present study (Tables I and II). This species was found infected by Leishmania (Viannia) sp. in Além Paraíba in the neighbouring State of Minas Gerais (Rangel et al. 1985).

As shown in Table II, the most abundant species in Area II were L. hirsuta, which comprised $38.8 \%$ of all sand flies collected, L. fischeri (Pinto) (15.4\%) and L. whitmani (Antunes \& Coutinho) $(14.4 \%)$. These three species were collected throughout the year, albeit in greater number during the cooler, drier months. Samples from this area also included the first specimens of L. misionensis (Castro) to be collected in Rio de Janeiro. This species was described from a female collected in Argentina (Castro 1959). The male was described, together with a redescription of the female, from specimens collected in Minas Gerais (Martins et al. 1977) and this species was subsequently collected in the Brazilian states of Bahia (Azevedo et al. 1996) and Rio Grande do Sul. Specimens from Rio Grande do Sul were found to be infected with Le. (V.) braziliensis (Silva \& Grunewald 1999).

The predominant anthropophilic species in intra/peridomiciliary collections in Area III (Table III) was L. intermedia (Lutz \& Neiva), as has been observed in other studies in Rio de Janeiro. Large numbers of L. whitmani and L. migonei (França) were also collected. These two species were abundant in the stable containing horses and cattle. $L$. intermedia predominated in both the manioc plantation and the chicken house. The differences in the relative frequencies of the three species collected by CDC light trap in the three stations are highly significant $\left(\chi^{2}=2,848.85 ; \mathrm{df}=11 ; \rho<\right.$ 0.0001 ) and consistent across collections (data not shown).

Both L. whitmani and L. intermedia have been considered as important vectors of ACL in Brazil (Aragão 1922, Forattini 1960, Mayrink et al. 1979, Rangel et al. 1984, 1990, Taniguchi et al. 1991, Falqueto 1995) and were both collected in all the study areas, $L$. intermedia was frequently collected around houses and L. whitmani was the third most abundant species in domestic animal shelters. Both species are abundant in the ACL focus of Posse, Rio de Janeiro, with L. whitmani being the more aggressive man-biter (Souza et al. 2000).

Further studies comparing the sand fly fauna of well-preserved and deforested areas are impor-

TABLE II

Sand fly fauna of Fazenda Bom Retiro Natural Heritage Reserve (secondary forest), Casimiro de Abreu, RJ, Brazil; July 1996 - June 1998

\begin{tabular}{|c|c|c|c|c|c|c|c|}
\hline \multirow{3}{*}{ Sand fly species } & \multicolumn{5}{|c|}{ Banana plantation } & \multirow{3}{*}{ Total } & \multirow{3}{*}{$\%$} \\
\hline & \multicolumn{2}{|c|}{ CDC light trap } & \multicolumn{2}{|c|}{ Shannon trap } & \multirow{2}{*}{$\frac{\text { Human bait }}{\mathrm{F}}$} & & \\
\hline & $\mathrm{F}$ & M & $\mathrm{F}$ & $\mathrm{M}$ & & & \\
\hline \multicolumn{8}{|l|}{ Brumptomyia guimaraesi } \\
\hline (Coutinho \& Barretto, 1941) & 11 & 12 & 1 & 5 & 0 & 29 & 0,6 \\
\hline Lutzomyia longipalpis (Lutz \& Neiva, 1912) & 11 & 39 & 0 & 3 & 1 & 54 & 1,2 \\
\hline L. fischeri (Pinto, 1926) & 183 & 193 & 143 & 163 & 6 & 688 & 15,4 \\
\hline L. shannoni(Dyar, 1929) & 53 & 54 & 62 & 104 & 30 & 303 & 6,8 \\
\hline L. barrettoi(Mangabeira, 1942) & 19 & 20 & 20 & 17 & 0 & 76 & 1,7 \\
\hline L. intermedia (Lutz \& Neiva, 1912) & 104 & 89 & 89 & 109 & 5 & 396 & 8,9 \\
\hline L. whitmani(Antunes \& Coutinho, 1939) & 182 & 130 & 134 & 125 & 72 & 643 & 14,4 \\
\hline L. hirsuta (Mangabeira, 1942) & 484 & 526 & 299 & 349 & 75 & 1.733 & 38,8 \\
\hline L. monticola (Costa Lima, 1932) & 76 & 60 & 62 & 48 & 15 & 261 & 5,8 \\
\hline L. misionensis(Castro, 1959) & 81 & 75 & 60 & 72 & 0 & 288 & 6,4 \\
\hline Total & \multicolumn{2}{|c|}{2,402} & \multicolumn{2}{|c|}{1,865} & 204 & 4,471 & 100 \\
\hline
\end{tabular}


tant to our understanding of how environmental changes might affect the transmission of Leishmania in Rio de Janeiro and other parts of Brazil. The results of such studies could also help to explain the increasing urbanization of ACL and how this might be related to changes in sand fly fauna composition and behaviour.

\section{ACKNOWLEDGMENTS}

To Dr Alexandre A Peixoto for suggestions on the manuscript. To Prof. João Carlos Peixoto, Federal University of Rio de Janeiro, for assistance with illustrations. To Dr Dionísio Pesamillio, chief of the "Poço das Antas" Biologial Reserve and Mr Luis Nelson Faria Cardoso, owner of Fazenda Bom Retiro Natural Heri-
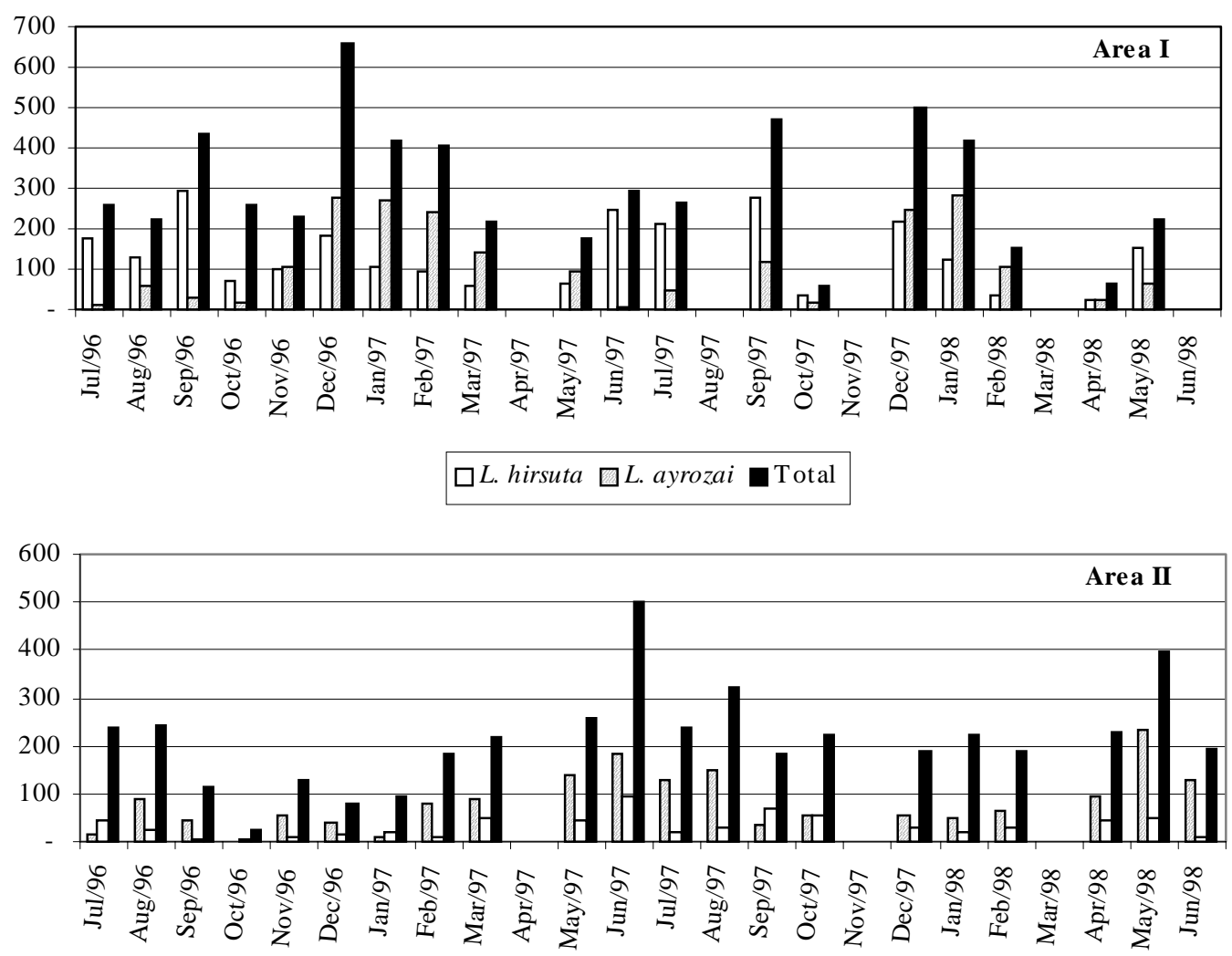

$\square$ L. hirsuta $\square$ L. fischeri $\square$ Total

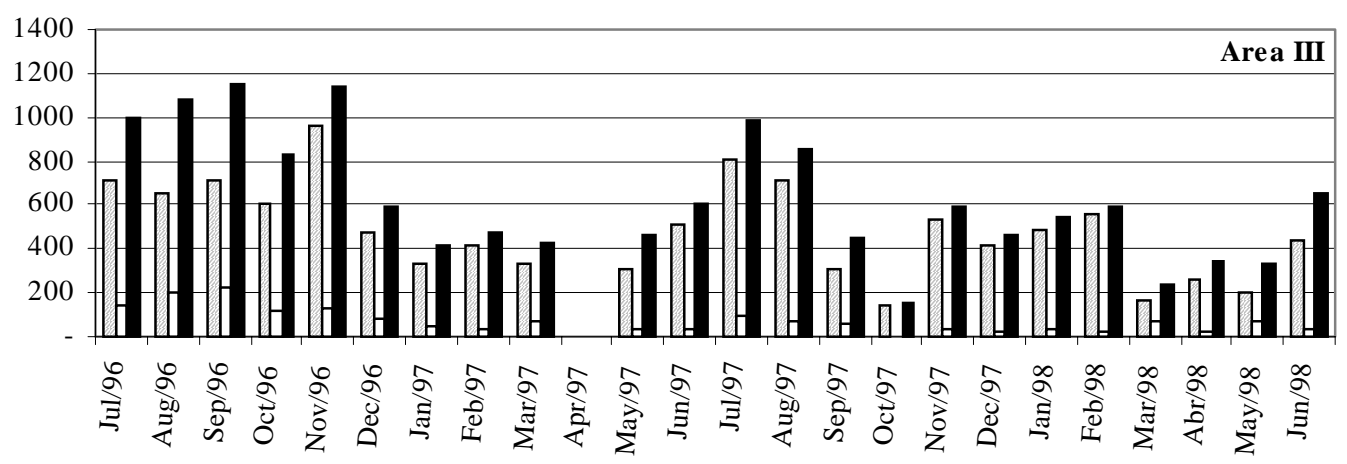

$\square$ L. intermedia $\square$ L. migonei $\square$ Total

Fig. 2: seasonal variation in the numbers of the most common species collected in each of the three study areas: Area I: mature secondary forest; Area II: secondary forest; Area III: in and around houses 


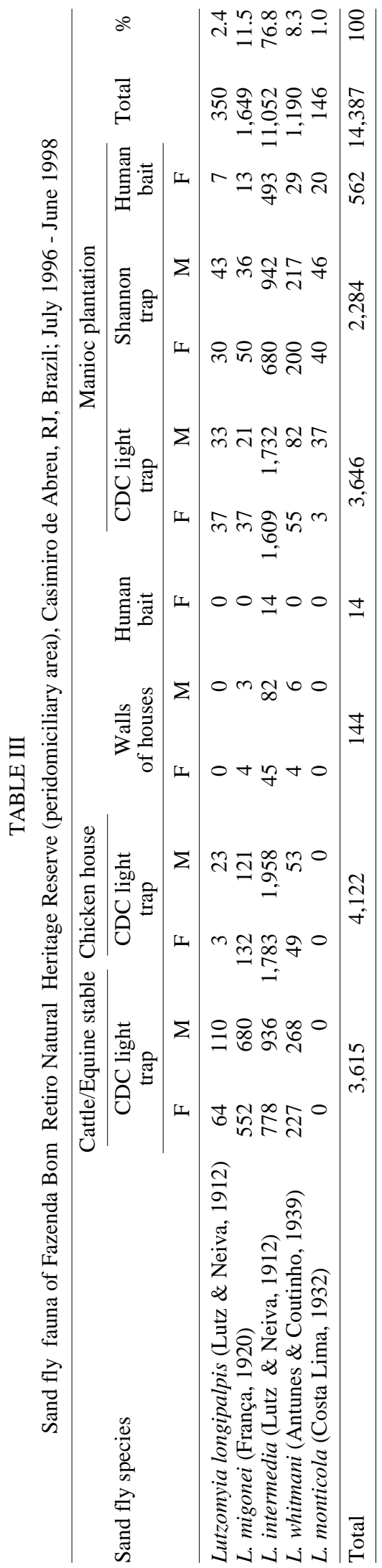

tage Reserve, for support in field work. To all employees and researchers of the study areas who contributed in some way to this work. To Mr Luiz Henrique Costa for technical support in field work.

\section{REFERENCES}

Aguiar GM, Soucasaux T 1984. Aspectos da ecologia dos flebótomos do Parque Nacional da Serra dos Órgãos, Rio de Janeiro. I - Frequiência mensal em isca humana (Diptera, Psychodidae, Phlebotominae). Mem Inst Oswaldo Cruz 79: 197-209.

Aguiar GM, Schuback PD, Vilela ML, Azevedo ACR 1985. Aspectos da ecologia dos flebótomos do Parque Nacional da Serra dos Órgãos, Rio de Janeiro. II - Distribuição vertical (Diptera, Psychodidae, Phlebotominae). Mem Inst Oswaldo Cruz 80: 187 194.

Alexander B 2000. Sampling methods for phlebotomine sandflies. Med Vet Entomol 14: 109-122.

Aragão HB 1922. Transmissão da leishmaniose tegumentar no Brasil pelo Phlebotomus intermedius. Brasil Médico 36: 129-130.

Azevedo ACR, Vilela ML, Souza NA, Andrade-Coelho CA, Barbosa AF, Firmo ALS, Rangel EF 1996. The sand fly fauna (Diptera: Psychodidae: Phlebotominae) of a focus of cutaneous leishmaniasis in Ilhéus, State of Bahia, Brazil. Mem Inst Oswaldo Cruz 91: 75-79.

Castro M 1959. Nota sobre flebotominae argentinos con la descripción de Flebotomus misionensis n. sp. (Dip. Psych). Primeiras Jornadas Entomoepidemiologicas Argentinas 2: 331-334.

Falqueto A 1995. Especificidade Alimentar de Flebotomíneos em Duas Áreas Endêmicas de Leishmaniose Tegumentar no Estado do Espírito Santo, PhD Thesis, Instituto Oswaldo Cruz, Rio de Janeiro, $84 \mathrm{pp}$.

Forattini OP 1960. Novas observações sobre a biologia de flebótomos em condições naturais (Diptera: Psychodidae). Arch Hig Saúde Publ 25: 209-215.

Mayrink W, Willians P, Coelho MV, Dias M, ViannaMartins A 1979. Epidemiology of dermal leishmaniasis in the Rio Doce Valley, State of Minas Gerais, Brazil. Ann Trop Med Parasitol 73: 123-137.

Martins AV, Silva J, Falcão AL 1977. Estudos sobre os flebótomos do estado de Minas Gerais. XIII: descrição do macho e redescrição de fêmea de Lutzomyia misionensis (Castro,1960) (Diptera, Psychodidae, Phlebotominae). Rev Bras Biol 96: 75-79.

Rangel EF, Azevedo ACR, Andrade CA, Souza NA, Wermelinger ED 1990. Studies on sandfly fauna (Diptera: Psychodidae) in a focus of cutaneous leishmaniasis in Mesquita, Rio de Janeiro State, Brazil. Mem Inst Oswaldo Cruz 85: 39-45.

Rangel EF, Ryan L, Lainson R, Shaw JJ 1985. Observations on the sandfly (Diptera: Psychodidae) fauna of Além Paraíba, State of Minas Gerais, and the isolation of a parasite of the Leishmania braziliensis complex from Psychodopygus hirsuta hirsuta. Mem Inst Oswaldo Cruz 80: 373-374.

Rangel EF, Souza NA, Wermelinger ED, Barbosa AF 1984. Infecção natural de Lutzomyia intermedia 
(Lutz \& Neiva, 1912) em área endêmica de leishmaniose tegumentar no Estado do Rio de Janeiro. Mem Inst Oswaldo Cruz 79: 395-396.

Silva OS, Grunewald J 1999. Contribution to the sandfly fauna (Diptera: Phlebotominae) of Rio Grande do Sul, Brazil and Leishmania (Viannia) infections. Mem Inst Oswaldo Cruz, 94: 579-582.

Souza NA, Vilela ML, Andrade-Coelho CA, Rangel EF 2000. Lutzomyia intermedia (Lutz \& Neiva, 1912) e Lutzomyia whitmani (Antunes \& Coutinho, 1939) ocorrendo em simpatria em área de transmissão de leishmaniose tegumentar americana no Estado do Rio de Janeiro. Rev Soc Bras Med Trop 33 (Supl.I): 183.
Sudia WD, Chamberlain RW 1962. Battery-operated light trap, an improved model. Mosquito News 22: 126-129.

Taniguchi HH, Tolezano JE, Correa FMA, Moraes RHP, Veiga RM, Marassa AM 1991. Epidemiologia da leishmaniose americana no Estado de São Paulo, Brasil. 1. Composição da fauna flebotomínica no município de São Roque, região de Sorocaba. Rev Inst Adolfo Lutz 51: 23-30.

Young DG, Duncan MA 1994. Guide to the identification and geographic distribution of Lutzomyia sandflies in Mexico, the West Indies, Central and South America (Diptera: Psychodidae). Mem Amer Entomol Inst 54: 1-881. 